\title{
REFLECTIONS ON THE INTERFACE OF TREATIES AND RULES OF PROCEDURE: TIME FOR FEDERAL "LONG-ARM" LEGISLATION
}

\section{J. Dickson Phillips* and PaUl D. Carrington**}

The Federal Rules of Civil Procedure apply to all litigants in federal courts whatever their nationality. In our view, this is as it should be. That foreign nationals may find civil procedure in the United States onerous is not a consideration that can be assigned weight in the general governance of our courts, which must try to treat all litigants the same.

Moreover, civil justice in America is a primary means of law enforcement; those who compete in our national economy ought, except in compelling circumstances, to be subject to the same modes of law enforcement as are their American competitors.

Nonetheless, because one size does not always fit all, modest accommodation to the special interest of foreign litigants may be appropriate in the same way that modest accommodation is made to special substantive concerns. ${ }^{1}$ If and when special accommodation of foreign interests ought be made in the text of procedure rules, who should be responsible for making them?

There is a five-tiered process for rulemaking. ${ }^{2}$ Pursuant to the Rules Enabling Act, amendments to the Rules generally receive first consideration in the Advisory Committee on Civil Rules of the Judicial Conference of the United States; its recommendations are then reviewed by a standing committee on rules; then by the Judicial Conference itself; then promulgated by the Supreme Court, subject to passive review by Congress. None of these organs except Congress seems to us competent to entertain requests from foreign nationals or governments for special consideration in the framing of procedure rules. No part of the judicial branch is fit to consider either the costs or benefits of special exemptions from the burdens and duties of civil litigation.

Foreign relations are in the first instance the concern of the Executive Branch; it negotiates treaties. It also participates in court rulemaking through its representation on the Judicial Conference committees. But it does not

\footnotetext{
Copyright $(9) 1994$ by Law and Contemporary Problems

* Senior United States Circuit Judge, U.S. Court of Appeals for the Fourth Circuit. Member, Advisory Committee on the Civil Rules, Judicial Conference of the United States, 1986-1992.

** Chadwick Professor of Law, Duke University School of Law. Reporter, Advisory Committee on Civil Rules, Judicial Conference of the United States, 1985-1992.

1. E.g., Fed. R. Civ. P. 9(b) (averments of fraud and mistake must be made with particularity);

Fed. R. Civ. P. 14(c) (special rule for impleading where plaintiff asserts admiralty or maritime claim).

2. For a fuller description, see Paul D. Carrington, Making Rules to Dispose of Manifestly Unfounded Assertions: Exorcising the Bogy of Non-Trans-Substantive Rules, 137 U. PA. L. REV. 2067, app. at 2119-29 (1989).
} 
control procedural rulemaking and has no particular responsibility for the quality of civil justice in our courts. For this reason, it would not be appropriate to give carte blanche to the Executive to trade special consideration in our court rules for such benefits as it might secure in any international transaction or relation satisfactory to it. It seems to these authors that the place to resolve any conflicts between the Executive's concerns in foreign relations and the courts' concern for even-handed civil justice is in Congress.

Thus, the Rules must certainly be reconciled with international agreements negotiated by the Executive and ratified by Congress, and when the interface of the Rules with such treaties present issues, the primary forum for their resolution ought to be Congress. The Judicial Branch can make any accommodations clearly required by treaties, but should flag any doubtful matters for consideration by Congress. We regret that this was not the process followed with respect to the 1993 revision of Rule 4 .

The relation between Rule 4 and the Hague Convention on the Service of Judicial Documents ${ }^{3}$ (and other treaties) had been on the agenda of the Advisory Committee on Civil Rules for several years when we joined that Committee in the mid-1980s. It had been suggested that the Rule should call attention to the international agreement as an available method of effecting service of a summons and complaint on international defendants. At the same time, the Committee proposed to revise Rules 26 and 44 to fit them to other treaties.

There were at least five other suggestions then pending for the revision of Rule 4, and it was decided that the then-existing text could not absorb them all. Accordingly, as suggested by at least one of its academic correspondents, the Committee undertook to rewrite the Rule from stem to stern.

While the Committee was working on the Rule, the Supreme Court decided Volkswagenwerk Aktiengesellschaft v. Schlunk ${ }^{4}$ holding that an Illinois state court could invoke its jurisdiction over a German manufacturer by serving process on its subsidiary without sending documents to Germany for service there, and hence without complying with the Hague Service Convention. It was of course presumed that the officers of the subsidiary would faithfully inform the parent corporation of the claim made against it. The Court reviewed the history of the Convention and concluded that, although mandatory, it had no application where jurisdiction could be effected without sending a "judicial document" into a foreign country. ${ }^{5}$ Volkswagen argued that because the subsidiary would be expected to transmit the summons and complaint to its parent, American judicial documents would enter Germany in a manner not approved by the Convention. ${ }^{6}$ The Court unanimously rejected this argument,

3. Convention on the Service Abroad of Judicial and Extrajudicial Documents in Civil or Commercial Matters, opened for signature Nov. 15, 1965, 20 U.S.T. 361, 658 U.N.T.S. 163 [hereinafter Hague Service Convention].

4. 486 U.S. 694 (1988).

5. Schlunk, 486 U.S. at 707-08.

6. Id. at 706-07. 
stating that "[t]he only transmittal to which the convention applies is a transmittal abroad that is required as a necessary part of service."7

In 1983, in a seemingly unrelated enactment, Congress had itself modified Rule 4 to provide for "service-by-mail.". This was a misnomer that may have misled some plaintiffs. What the statutory Rule 4 authorized was the use of the mail to request a waiver of formal service of process; a defendant refusing to do so would then be formally served, but the Rule then imposed the expense of formal service on the defendant unless the defendant could show good cause for refusing to waive the formality, a very difficult showing to make. One of the aims of the Civil Rules Committee in amending Rule 4 was to clarify the nature of this congressionally created device. Changing the nomenclature and reorganizing the text, its revision dispensed with the confusing phrase implying that service could be effected by mail. The new Rule simply authorized plaintiffs to "invite waiver" of formalities, and retained the device of imposing on the defendant the cost of those formalities unless it should later appear that there was a good reason to refuse the requested waiver.

This cost-shifting mechanism first introduced into Rule 4 by Congress was generally consistent with recent revisions of the discovery rules and Rule 11 , having the aim of making parties bear the cost of needless procedure caused by their intransigence, even if in due course they later prevailed on the merits. Even a litigant having a meritorious claim or defense, the Rules now say, is not entitled to impose needless costs on an adversary. This principle makes sense in its application to Rule 4. An example is the defendant residing in a guarded condominium. A process server may have to lie in wait for such a defendant in order to effect service by personal delivery. That is costly. There is no sound reason for not requiring defendants to cooperate in avoiding that cost.

It seemed to the Committee that this sensible principle had appropriate application to some defendants in foreign countries, for many such defendants are in the position of the defendant in the guarded condominium. We had particularly in mind defendants such as Toyota, which had secured a dismissal of at least one case because the plaintiff had failed to comply with the requirement of the Hague Convention that a complaint formally served thorough the Japanese Central Authority ${ }^{8}$ be translated into Japanese. ${ }^{9}$ As Judge Gibson had emphasized in his concurrence in that case, the result was substantial and needless cost imposed on the American plaintiff. Toyota could hardly contend that it is unable to read a document in English. The high cost of a lawsuit against Toyota gives it a marginal advantage in the pricing of its automobiles, at least insofar as it is competing with American manufacturers that can be sued much less expensively. This last consideration had been emphasized by the Supreme Court in its reading of the Evidence Convention

7. Id. at 707. Justice Brennan, supported by Justices Marshall and Blackmun, concurred separately, but expressed agreement with the language quoted here. Id. at 710 .

8. The institution created pursuant to the Hague Service Convention, supra note 3, art. 2,20 U.S.T. at 362, 658 U.N.T.S. at 165-67.

9. Bankston v. Toyota Motor Corp., 889 F.2d 172 (8th Cir. 1989). 
in Société Nationale Industrielle Aérospatiale v. United States District Court for the Southern District of Iowa. ${ }^{10}$

For these reasons, the Civil Rules Committee proposed explicitly to make the waiver-of-service provision applicable to defendants outside the United States. To make it clear that the letter inviting waiver is not a "transmittal that is a necessary part of service," 11 and indeed that it is not a "judicial document," the Committee deleted the requirement that a copy of the summons be included in the letter of invitation. Such a letter should include a copy of the complaint that the plaintiff proposes to serve on the defendant if formal service is not waived, but not a copy of a summons issued by a court.

Of course, as under the former service-by-mail provision, the invited waiver letter would not effect service of process. A litigant such as Toyota could insist on its rights under the Service Convention and require that the complaint be translated into Japanese. The only consequence of such insistence under the proposed rule would be to impose the cost of that needless translation on Toyota. Such cost-shifting would not be imposed on a defendant not fluent in English, for such a defendant would have a sufficient reason for insisting on formal service pursuant to the Convention.

The Civil Rules Committee considered the possibility that one or more foreign governments who were signatories to the Convention might challenge the proposed rule as inconsistent with the Convention. In light of the Supreme Court opinions, the Committee thought such a challenge weak, if not altogether untenable. On the other hand, given Schlunk, the proposed rule change was not essential to avoiding the result in the Toyota case, at least if state law allows service thorough a subsidiary, as the Illinois law did in Schlunk.

In weighing these considerations, it was conclusive in our minds and in the minds of many members of the Committee that our Committee lacked competence to make foreign relations law. The Civil Rules Committee is competent at weighing the effectiveness of proposed rules to comport with the aims of the Rules Enabling Act ${ }^{12}$ and to achieve "just, speedy, and inexpensive" determination of civil actions. ${ }^{13}$ But the Committee is prohibited from fashioning different rules for different classes of cases to achieve domestic substantive aims ${ }^{14}$ and can hardly claim superior license to pursue a foreign policy.

As now required, the Committee's deliberations on Rule 4 were extremely open and widely publicized. The Executive Branch participated at every stage and supported the proposed revision of Rule 4 in the form in which it was sent to the Supreme Court in 1990. Not only were there public hearings in Chicago, but the proposal was discussed with academic audiences in Germany and in

\footnotetext{
10. 482 U.S. 522,540 n. 25 (1987).

11. Compare with the language of Schlunk quoted supra at note 7 .

12. 28 U.S.C. $\$ 2072(1988)$

13. FED. R. Civ. P. 1.

14. For analysis, see Paul D. Carrington, "Substance" and "Procedure" in the Rules Enabling Act, 1989 DUKE L.J. 281.
} 
Japan. As best we recall, only one objection to the proposed revision of Rule 4 was timely received. That came from a Chicago lawyer representing Toyota, who asserted categorically that the Rule would violate the Service Convention, but who made no further argument.

We were not persuaded that this was so, and in any event, regarded the issue as one better resolved at another level. Hence, our recommendation went forward through the Standing Committee on Rules and the Judicial Conference, both of whom unanimously sustained our view. It was only when the proposed Rule reached the Supreme Court that a serious challenge was made. The belated challenge came, rather surprisingly, from the British Embassy. It seems that the Supreme Court, having never conducted a hearing on the promulgation of a rule of court, was reluctant to conduct a hearing on an issue raised by a foreign government. The Rule was therefore remanded to us to respond to the British complaint. By this time, the Department of State was also manifesting interest. Apparently, there was some negotiation between officers of the Judicial Conference and others resulting in agreement that the Rule could go forward as proposed, but with the cost-shifting feature not applicable to litigants outside the United States. And so it did; in that form, it is now the federal law. A part of the picture in this negotiation was Schlunk, which greatly diminished the significance of the proposal. The tempest was in a teapot.

Whether the resulting Rule is sound is open to question. Seemingly, the invited waiver device ought not be used by a plaintiff in an international case, because the defendant has no real incentive to waive, and the result will be useless delay as well as needless expense if formal service is then to follow. In that respect, the present Rule may be a trap for the unwary. Also, it seems strange that the cost-shifting device is not available even where the defendant is in a country that is not a signatory to the Hague Convention. ${ }^{15}$ It is not easy to understand why the absence of the cost-shifting device should satisfy those foreign governments who take offense at the use of the mails to send copies of complaints to their citizens.

In hindsight, it seems to us that the issue, small though it was, should have been presented to Congress for resolution. In fact, the Committee did specifically call to the attention of Congress another change in Rule 4 having international implications. This was the default long-arm provision of subdivision (k). ${ }^{16}$ Having some doubt whether that provision was one that the Supreme Court was empowered to promulgate, the Committee sent it forward

15. This issue was apparently debated in the Judicial Conference. See Excerpt from the Report of the Judicial Conference Committee on Rules of Practice and Procedure 3 n.3 (Sept. 1992), reprinted in Amendments to the Federal Rules of Civil Procedure [hereinafter Amendments], 146 F.R..D. 401, 517 n.3 (1993). When the last vestige of cost-shifting was removed from the rule, the Conference created a dissonance with the Advisory Committee Notes, which continue to cite Bankston as a justification for the fee-shifting provision. Proposed Amendments to the Federal Rules of Civil Procedure and Forms 27 (Nov. 1992), reprinted in Amendments, supra, 146 F.R.D. at 561.

16. This revision was made in response to the suggestion of the Supreme Court in Omni Capital Int'l v. Rudolf Wolff \& Co., 484 U.S. 97, 111 (1987). 
with a questioning note. ${ }^{17}$ A similar note should have been attached to the invited waiver provision so that the issue could have been brought to the attention of Congress. With such a note attached, the Judicial Conference and the Court should have been content to pass the matter along to Capitol Hill.

Indeed, in reflecting on the matter, it seems to us that the time has come for Congress to enact a federal long-arm statute applicable to foreign firms sending their products or services into American markets. Such a statute could follow the pattern of 19th century state laws imposing jurisdiction on "foreign" corporations doing business in states other than those in which they are organized. ${ }^{18}$ Truly foreign corporations engaged in commerce in America should be required to designate an agent in this country who is authorized to receive service of a summons issued by an American court in any action arising out of that commercial activity. If they fail to do so, American plaintiffs should be authorized to effect service of a summons through any sales or managing agent of that corporation or its subsidiary who is found in the United States. The purpose and effect of such a law would be to facilitate the assertion of claims by American citizens against foreign enterprises engaged in commerce here, thereby placing such enterprises on a more nearly level playing field with their American competitors. Such as enactment could properly be proposed as an extension of the 1993 revision of subdivision (k) of Rule 4 and might be initiated by the Advisory Committee on Civil Rules as a proposal to Congress, by-passing the Supreme Court out of concern that such a reform should be reckoned something more than a mere rule of practice and procedure that the Court is authorized to promulgate by the Rules Enabling Act.

If this were done in this way, better civil justice would ensue, and the relations among the branches of government would be set right. The question whether judicial documents served on multinational corporations must be translated into their language would be resolved in the forum best suited to weigh the competing interests at stake.

17. Proposed Amendment to the Federal Rules of Civil Procedure and Forms 37 (Nov. 1992), reprinted in Amendments, supra note 15, 146 F.R.D. at 571.

18. See generally 1 ROBERT C. CASAD, JURISDICTION IN CIVIL ACTIONS $\$ 3.02$ (2d ed. 1991). 